Meta

Journal des traducteurs

Translators' Journal

\title{
Proactive Description for Useful Applications: Researching Language Options for Better Translation Practice?
}

\section{Rosa Rabadán}

Volume 50, numéro 4, décembre 2005

Pour une traductologie proactive - Actes

For a Proactive Translatology - Proceedings

Por una traductología proactiva - Actas

URI : https://id.erudit.org/iderudit/019874ar

DOI : https://doi.org/10.7202/019874ar

Aller au sommaire du numéro

Éditeur(s)

Les Presses de l'Université de Montréal

ISSN

0026-0452 (imprimé)

1492-1421 (numérique)

Découvrir la revue

Citer cet article

Rabadán, R. (2005). Proactive Description for Useful Applications: Researching Language Options for Better Translation Practice? Meta, 50(4).

https://doi.org/10.7202/019874ar
Résumé de l'article

Le postulat de départ de cette recherche est que la production d'applications utiles est une composante du processus de recherche, et qu'il revient au chercheur de faire passer ses découvertes, obtenues pendant la phase descriptive de base, à des " paquets de know-how » qui puissent être utilisés par d'autres professionnels / pour d'autres activités. Cet article démontre l'utilité d'une démarche contrastive basée sur corpus à travers la traduction en espagnol des formes anglaises du " passé progressif ". Les résultats sont proposés comme un inventaire de solutions « descriptivement prescriptives " que l'on peut employer autant dans la pratique que dans l'enseignement de la traduction. Ils sont aussi applicables au domaine de l'évaluation, en tant que filtre objectif lors de la vérification de solutions et/ou en tant que « tertium comparationis " pour interpréter les « changements » identifiés à partir de l'analyse descriptive typique de corpus parallèles (TSang-TCesp).
Ce document est protégé par la loi sur le droit d'auteur. L'utilisation des services d’Érudit (y compris la reproduction) est assujettie à sa politique d'utilisation que vous pouvez consulter en ligne.

https://apropos.erudit.org/fr/usagers/politique-dutilisation/ 


\title{
Proactive Description for Useful Applications: Researching Language Options for Better Translation Practice*
}

\author{
ROSA RABADÁN \\ University of León, León, Spain \\ dfmrra@unileon.es
}

\begin{abstract}
RÉSUMÉ
Le postulat de départ de cette recherche est que la production d'applications utiles est une composante du processus de recherche, et qu'il revient au chercheur de faire passer ses découvertes, obtenues pendant la phase descriptive de base, à des « paquets de know-how » qui puissent être utilisés par d'autres professionnels / pour d'autres activités. Cet article démontre l'utilité d'une démarche contrastive basée sur corpus à travers la traduction en espagnol des formes anglaises du « passé progressif ». Les résultats sont proposés comme un inventaire de solutions « descriptivement prescriptives » que l'on peut employer autant dans la pratique que dans l'enseignement de la traduction. Ils sont aussi applicables au domaine de l'évaluation, en tant que filtre objectif lors de la vérification de solutions et/ou en tant que « tertium comparationis » pour interpréter les « changements » identifiés à partir de l'analyse descriptive typique de corpus parallèles (TSang-TCesp).
\end{abstract}

\begin{abstract}
The initial assumption for this inquiry is that producing useful applications is part of the research process, and that it is the duty of the researcher to 'transfer' the knowledge gained in basic, descriptive research to 'know-how' packages to be used by other professionals/ in other activities. This paper illustrates a contrastive corpus-based research procedure using a case study: the translation of English 'Past Progressive' forms into Spanish. The results are presented as an inventory of 'descriptively prescriptive' translation solutions to be used by practitioners and translation trainers. They can also be used in the area of evaluation, as an objective filter to assess language performance in translations or as a descriptive tertium comparationis for the interpretation of translational shifts obtained from work done (exclusively) with parallel corpora (STEng- TTSp).
\end{abstract}

\section{MOTS-CLÉS/KEYWORDS}

application, descriptive research, contrastive analysis, corpus-based research, past progressive

\section{Introduction}

Contemporary translation research is an exceptionally diverse field which boasts a variety of models and /or approaches that fruitfully contribute to the advancement of this and other fields in various directions. The same cannot be said of the transfer of these 'advancements' to areas such as actual translating, quality assessment, editing, and even certain aspects of research.

There seem to be several reasons for this state of affairs. On the one hand, 'applied translation studies', is considered to be 'outside' the central core of the discipline (Toury 1995). There is also the unwillingness to deal with the prescriptivism necessarily involved when considering what is and what is not correct in textual and linguistic terms. On the other hand, the idea that applications are not the business of the researcher and should be left to the practitioners of the applied activity (Toury 1995) has delayed work in fundamental areas. It is quite evident that straight descriptive and/or explanatory results cannot be applied directly to some other activity, not even by those who have produced them. 
Research done in other areas such as corpus linguistics or contrastive analysis face the same problems mentioned above, but for different reasons. Contrastive analysis does not necessarily address applied cross-linguistic problems as it tends to stop at the descriptive "similarity and divergence' stage. Moreover, the analytical tools are generally inadequate to deal with applied translation questions. Corpus linguistics and its accompanying technologies have brought about an enormous change, both qualitative and quantitative, to the way 'language in use' is researched. But they cannot automatically generate solutions to cross-linguistic problems as computer aids are unable to process the semantic and pragmatic factors.

My starting assumption is that producing useful applications is part of the research process, and that it is the duty of the researcher to 'transfer' the knowledge gained in basic, descriptive research to 'know-how' packages to be used by other professionals/ in other activities.

\section{Aim}

This paper sets out to show how to (proactively) research language problems for an applied goal. This will be done by means of a contrastive and descriptive corpus-based research procedure. The aim is to show that descriptive translation data, combined with contrastive analysis of non-translated language, is a sound way to obtain a 'descriptively prescriptive' inventory of (correct) 'translation solutions' when translating/ assessing/editing, etc. The languages involved are English and Spanish and the 'problem' chosen to illustrate the procedure is the rendering of the English Past Progressive into Spanish. Although the procedure is methodologically neutral, the results apply to translation from English into Spanish.

\section{Procedure}

As this is not the focus of this paper - it has been dealt with elsewhere (Rabadán et al 2004) -, the research procedure will only be briefly described here. It includes the following steps: 1. identification of the problem and establishment of research question(s) 2. corpus material selection from both comparable and parallel corpora; 3. description in English and in Spanish separately; 4. juxtaposition of English-Spanish results; 5. contrast, 6. preparation of the results for application building. The initial comparability criterion (Chesterman 1998) is the 'principle of perceived similarity' (i.e., the 'naturally equivalent' form in the target language) and the linguistic perspective is basically functional, although no particular model of linguistic analysis (and no particular modelbound terminology) has been adopted. Findings from studies done within analytic frameworks other than the functional one have been included in this study whenever useful and/or convenient.

This study is based on comparable and translation empirical data obtained from three different corpora. The comparable, properly contrastive, data is drawn from two monolingual reference corpora: The Bank of English for English and the CREA (Corpus de Referencia del Español Actual) for Spanish. They are sources for building a tailor-made comparable corpus. Translation data for description has been extracted from the ACTRES corpus. A group of 100 randomly selected pairs contribute 'translation alternatives' to the basic 'perceived similarity solution' that have to be tested against further CREA data. A team of ten informants was recruited to provide semantic/pragmatic assessment of the empirical data where necessary.

\subsection{Identification of the Problem and Research Question(s)}

Although the English Past Progressive shares certain values with the $<$ Estar + gerund $>$ periphrasis, it is far from evident what the central functions of each construction are. English uses the Progressive when expressing ongoing events, so as to mark the 'incompleteness' or 'nonculmination' of the action/ event (Kratzer 2004:416). Spanish commonly marks the absence of an end-closure of the action, process or event by means of an imperfecto (Rabadán 2005). While English may employ the Progressive to indicate future arrangements, Spanish tends to resort to verbal forms associated with 'virtuality' or 'hypothesis'. This is evidence that forms have different meaning associations in different languages, even if there exists a 'formal equivalent'. Awareness 
of the fact that what is appropriate in English does not necessarily carry over into Spanish is the first step towards mapping English meanings onto Spanish forms.

There seems to be general agreement that the English Progressive forms have a central meaning which can be further specified in a number of other more specific subsidiary functions. This basic underlying meaning has been given different designations, '(limited) duration' (Leech 1987:19), 'dynamicity' (Huddleston \& Pullum 2002:167), or more recently 'susceptibility to change'

(Williams 2002:87). It includes at least two components: 'duration'(understood as a whole, as part of that whole, as continuation or repetition, as a process with an imminent conclusion or with no foreseeable conclusion), and 'temporariness'. This second component is frequently reinforced by other expressive resources aiming at contextually defining the moment or period of time during which the occurrence predicated by the verb is valid and /or relevant.

A further meaning conveyed by the progressive and related to both 'duration' and 'temporariness' is '(temporary) habit'. There is some disagreement among linguists whether it is a 'habit' at all, since 'habitual actions' tend to be considered as permanent, not transitory. To avoid this pitfall some authors (Scheffer 1975:91) have dubbed this function 'customary event'. I prefer to retain 'temporary habit' for the sake of conceptual and terminological congruence.

The English Past Progressive also has a 'future' actualization, or rather a 'futurate meaning'. This is 'a reading of a sentence with no obvious means of future reference, which nevertheless has a future-oriented eventuality' (Copley 2000:1). Very frequently, progressive form futurates convey the idea of 'plan or schedule', even 'intention', which is linked to modal meanings (Portner 1998).

The periphrastic construction $<$ Estar + gerund $>$ is generally taken to be the 'Spanish progressive' although the general view is that it is not part of the regular tense paradigm ${ }^{1}$. It basically expresses an ongoing process or event framed in the temporal axis provided by the corresponding tense. $<$ Estar + gerund $>$ always implies a non-culminative aspect, that is, the action or event may cease but the end of the process or activity has not been reached nor its goals attained (Kratzer 2004:416). This construction is particularly context-sensitive and its use and interpretation frequently depend on other factors, namely, the temporal relations expressed by $\langle$ Estar $\rangle$, the semantics of adverbial characterization in the context, the semantics of the gerund and lexical aspect. As a result of this, $<$ Estar + gerund $>$ may express a considerable number of (progressive) aspectual meanings (Gómez Torrego 1988:136-147) such as inchoative, imminent conclusion, intensive, iterative, distributive, frequentative, etc.

It has also been pointed out that the interplay between the above mentioned factors may give rise to (co)occurrence restrictions, which occasionally result in defective tense morphology (not conjugated in all persons) (Laca 2004:437). For some authors (Fernández de Castro, 1999:245250) this frequent periphrasis indicates 'actualization of a verbal process in a given period' and 'progressive gradation', which take us back to the core features of 'temporariness' and 'durative, ongoing process or event'.

$<$ Estar + gerund $>$ is not particularly suited for denoting 'habit', as this is more commonly done by means of the corresponding tenses. The (rare) exception is when the habitual occurrence is restricted to a contextually defined period of time, that is, when it is a 'temporary habit' (Yllera 1999:3412).

The research questions addressed here are: how does Spanish express the meaning(s) conveyed by the English Past Progressive? Are there real alternatives to the 'formal equivalent' $<$ Estar + gerund $>$ ? How is the mapping of English form(s) to meaning function(s) transferred into Spanish (Higgingbotham 2004:329)?

\subsection{Common Ground: Cross-Linguistic Semantic Labelling}

From the above account it seems that the English Past Progressive and the Spanish periphrasis $<$ Estar + gerund $>$ share, at least, the basic meanings of progression and (temporary) habituality. In order to identify other possible meanings which could be relevant for our applied cross-linguistic purpose, empirical data will be obtained from the ACTRES translation corpus. The evidence found will be used to build a - for the time being- tentative tertium comparationis. 
In order to discover possible departures from the initial 'perceived similarity' equivalence, the translation corpus ACTRES was queried for Past Progressive constructions and 100 pairs were selected at random. The most salient regularity ${ }^{2}$ is the fairly long inventory of solutions given to this form in Spanish, although the more central forms seem to be the imperfecto and a number of aspectual periphrases also conjugated in this tense, which contribute $48 \%$ and $28 \%$ of all cases respectively.

Other tenses also favoured by translators (and difficult to explain) are the pretérito (7\%), the present tense (5\%), either as a straight tense or as a periphrasis (extremely rare), and the perfect tenses $(4 \%)$.

A third group of solutions includes the imperfecto in the subjunctive (4\%), the conditional mood $(1 \%)$ and a number of modal constructions $(3 \%)$.

Table 1. Spanish translation solutions to English Past Progresive

\begin{tabular}{|l|l|l|}
\hline ENGLISH & SPANISH SOLUTIONS & $\mathrm{N}^{\circ} \& \%$ \\
\hline \multirow{5}{*}{ PAST } & IMPERFECTO & 48 \\
\cline { 2 - 3 } & PROG PERIPHRASES IMP & 20 \\
\cline { 2 - 3 } & OTHER PERIPHRASES IMP & 8 \\
\cline { 2 - 3 } & PRETERITO & 7 \\
\cline { 2 - 3 } & IMPERFECTO SUBJ & 4 \\
\cline { 2 - 3 } & PRESENT TENSES & 5 \\
\cline { 2 - 3 } & MODAL CONSTRUCTIONS & 3 \\
\cline { 2 - 3 } & PERFECT TENSES & 4 \\
\cline { 2 - 3 } & CONDITIONAL & 1 \\
\hline 100 & TOTAL & 100 \\
\hline
\end{tabular}

The overwhelming use of the imperfecto as the first translation solution has to be taken into account when establishing cross-linguistic distinctions. The question is when and why each of the translation solutions in table 1 is used: if Spanish consistently distinguishes between the straight imperfecto and the periphrastic form(s), there must be some reason(s) for it, either semantic or contextual. The answer obviously lies in searching for possible regularities of meaning-form association and, if they are obtained, establishing a tentative tertium comparationis to be used in the contrast phase of the analysis.

The Spanish periphrastic forms offer the possibility of distinguishing between a rather homogeneous progressive referring to the unfolding development of the action/event taken as a whole (1_prACTRES), and what Prat (1996:302) calls 'distributive progressive', which incorporates the notion of 'gradualness'. The periphrastic is the rule when an action/event in progress is interrupted by a second action (41_prACTRES); it also seems to be preferred when the English progressive indicates 'mid-action perspective' (66_prACTRES), although instances of an imperfecto with convenient adverbial modification have also been found (64_prACTRES) Compare the following pairs:

By 13 September, the Germans had contained the landing and were threatening to drive a wedge between the British and American corps with an armour attack.

A pesar de ello, el 13 de septiembre los alemanes habían contenido el avance aliado. Sus formaciones amenazaban con clavar una cuña entre los cuerpos de ejército británico y estadounidense, mediante un nuevo ataque de combate. (1_prACTRES)

The embassy's night operator was reading Time magazine's International Edition when the sound of her phone interrupted her.

La telefonista de guardia aquella noche estaba leyendo la revista Time cuando le interrumpió el sonido del teléfono. (41_prACTRES) 
They were arguing about polka-dots for some reason, Mother claiming that no one over the age of ten should be allowed to wear them.

Por algún motivo, estaban discutiendo sobre lunares, y mi madre afirmaba que a nadie mayor de diez años se le debería permitir llevarlos. (66_prACTRES)

After the row, while we were waiting at the bus stop for the bus back to Abbey, Holden-Dawes walked by with a young woman on his arm - quite a pretty young woman.

Tras la pelea, mientras esperábamos el autobús que nos llevara de vuelta a Abbey, pasó H-D con una joven cogida de su brazo, una joven bastante bonita. (64_prACTRES)

Likewise, there seems to be a tendency for 'more specific progressives' such as inchoative, continuative or gradual to be alternatively encoded by other periphrases. These unveil and actualize the particular meaning of the progressive English form, as in

Walking beside her, Langdon was already feeling the tingle of anticipation that accompanied his face-toface reunions with great works of art.

A su lado, Langdon ya empezaba a notar ese cosquilleo de impaciencia que siempre le invadía momentos antes de ponerse frente a las grandes obras de arte. (43_prACTRES)

Peering out from behind the canvas, she could see the guard was still trying desperately to raise someone on the walkie-talkie.

Asomando la cabeza por debajo del cuadro, vio que el guardia seguía intentando desesperadamente comunicarse con alguien a través del walkie-talkie. (53_prACTRES)

As the quarter progressed, evidence suggested that the economy was slowing. Additionally, the inflation environment remained favourable.

A medida que avanzó el trimestre, sin embargo, aparecieron señales de que la economía iba

desacelerándose, y el panorama de la inflación continuó siendo favorable. (97_prACTRES)

From the knowledge gained so far, we are now in a position to formulate a tertium comparationis in the form of meaning labels. To be useful, these labels need to be semantically discriminating and user-friendly in both applied research and practical uses.

'Progressive' [PR] indicates 'non-culminative ongoing process or event' considered in its entirety with or without limited duration. In other words, it designates a process that can cease or be interrupted but not attain an accomplishment or reach an end.

[PR]

The only light was coming from the window. I took this picture for myself, for its beauty and magic."

'Mereological progressive' [MPR] will be used to discriminate all those instances in which the actual process is seen as 'parts-of' the process as a whole (Bonomi 1997). Focusing on parts of the action/event produces meanings such as MPR-'inchoative', MPR-'imminent conclusion', MPR-'continuative', etc.

By this stage, natural leaders were coming to the fore, although one rather didactic and loud-mouthed entrant was beginning to cause strain among his muddied and sodden peers. [MPR] INCHOAT (30PRP_EN)

También como en el caso de la aventurera rusa, Crowley enseñó que el mundo $\mathbf{e}$ estaba entrando en una "Nueva Era" en la que, entre otras cosas, debería desaparecer el cristianismo (una tarea que Crowley intentó llevar a cabo con enorme entusiasmo). [MPR] INCHOAT (69 IMPPR_SP) 
"Debido a lo avanzado del verano austral", señalan los expedicionarios, "no encontramos hielo ni vimos témpanos hasta el 4 de enero, cuando el buque estaba entrando en el estrecho de Bransfield. [MPR] IMM CONCLUSION (68 IMPPR_SP)

Jim Leng, the new chief executive, said the destocking that affected second-half profits was coming to an end and indicated that investment would continue at a high level, roughly twice the level of depreciation. [MPR] IMM CONCLUSION (51-PRP_EN)

'Anticipatory past' [ATP] stands for those cases with a 'futurate reading', indicating 'plan or intention', which, as suggested above, links it to certain types of modality.

EXCITED schoolchildren thought their favourite pop stars were coming when they were told to expect a VIP visit. [ATP] (26-PRP_EN)

No examples of this function were found in the Spanish language data.

'Temporary habit' [TH] refers to some 'customary' event or situation occurring only during the time limit expressed by the context as opposed to 'habit in the past' which refers to a permanent, habitual circumstance.

At the time she was living at her mum's on a Leeds council estate. [TH] (254-PRP_EN)

Yo estaba estudianda en Tomelloso para colocarme en una oficina. Y romper ese círculo me habría sido muy difícil porque soy un rebelde pasivo. [TH] (233 IMPPR_SP)

'Hypothetical' [HYP] indicates 'unreal condition', a meaning which Spanish normally handles by means of subjunctives or conditional tenses and that English may encode by means of a Past Progressive tense.

Mr Al Fayed wanted the apartment to stay the way his son left it, as if he were coming back [HYP] (23PRP_EN)

No instances of [HYP] have been found in the CREA sample.

'Irrealis' [IRR], stands for a number of non-actual values that have also been named differently (Fleischman 1995; Pérez 1998) etc. Basically it applies to contexts expressing that something that was intended and /or planned to happen never did.

Mr Griffin pulled a chair forward for Rose. $<\mathrm{p}>$ We were coming to see you as soon as we'd had tea," he said. [IRR] (22-PRP_EN)

No Spanish example of this meaning function has been found.

\subsection{Selection English- Spanish}

Selecting a sample that is both representative and comparable from both monolingual corpora implies setting up a querying policy for each of the corpora. This 'policy' depends on the options offered by each of them and by the nature of the 'problem' being researched. On this occasion the fact that Spanish does not have a progressive 'tense' as part of the normal conjugation, but a rather 'peripheral' form usually perceived as the natural 'cross-linguistic equivalent' determined the first step: in Spanish the progressive form is fully conjugated in the two past tenses: the imperfecto and the pretérito (Rabadán 2005). Both of them need to be analyzed so as to distinguish the semantics of the progressive form from the functions normally associated with by the corresponding tense.

The second step concerns comparability. Since both monolingual corpora serve as "source corpora', the actual comparable corpus on which the analysis is to be based must be defined. 
Frequency lists were adopted as a limiting criterion and 10 high frequency English verbs ${ }^{3}$ chosen $^{-}$ randomly were searched. It was necessary to run the search to up to 45 Spanish verbs ${ }^{4}$ to match the output (2342 occurrences) of the English language corpus with 2400 (2109 imperfecto +291 pretérito) cases of 'perceived' Past Progressive in Spanish. Thus the basic requirement of comparability has been met.

A further step in the selection stage is representativeness (with all the usual limitations), which concerns, among other considerations, the size of the sample. This was solved using the formula : $n=N /\left((N-1) E^{2}+1\right.$ where ' $\mathrm{n}$ ' is the sample to be analysed and ' $\mathrm{N}$ ' the population, i.e., the total number of occurrences yielded by our searches and ' $E$ ' the estimative error (5\% ). The distribution of occurrences for both English and Spanish were statistically replicated in the samples to be analysed; values under 0.5 have been rounded off to the preceding unit, and those exceeding 0.5 to the next unit so as to always obtain discrete quantities (that is, the number of examples to be analyzed). The samples to be analyzed are thus 342 examples of English Past Progressive; 336 of Spanish <estar + gerund > in the imperfecto and 109 in the pretérito tense.

\subsection{Description}

\subsubsection{Description: English}

The representative sample of the occurrences of the English Past Progressive yielded the following meanings: $53 \%$ of the cases depict a basic 'non-culminative ongoing event in the past' meaning, which corresponds to the label 'progressive' [PR] as in

We were trying to break down barriers and become close friends," says Abi, 21, who plays the feisty Jodie Cooper in the teen show. [PR] (89-PRP_EN)

Nearly a quarter $(23 \%)$ of the examples show different, more specific aspectual meanings such as 'intensive', 'inchoative', 'limited duration', 'imminent conclusion', etc. Although these finer labels do not seem to be conclusively discriminating in terms of English/Spanish cross-linguistic considerations, the evidence we have gathered suggests that they should be separated from a more general [PR] label. They will be analysed as 'mereological progressive' [MPR] as in

Until that day in the hall, he didn't know we were seeing each other - Maria wanted it that way. I only went to the apartment to get her when he wasn't there. [MPR] INTENSIVE (1-PRP_EN)

By then the sun had all but disappeared, and the first few stars were coming out over the towering walls of Dun Cengarn. [MPR] INCHOAT (18-PRP_EN)

'Anticipatory past' [ATP] is depicted in over $8 \%$ of the cases. In all cases the meaning is 'planned future in the past'.

A solicitor friend had agreed to sign my affadavit, and she was coming round to the bedsit to do it. [ATP] (58-PRP_EN)

'Temporary habit' $[\mathrm{TH}]$ appears in $7 \%$ of the occurrences in the sample, as in

It was an even funnier sight when we did it in buckskins around Earl's Court, London, where he was living at the time. [TH] (256-PRP_EN)

Another $7 \%$ of the cases illustrates the function dubbed here 'hypothetical' [HYP],as in

She shook her head, opened her mouth as if she were trying to say something, only no words came out. [HYP] (98-PRP_EN) 
A very peripheral meaning is 'irrealis' [IRR], which occur in less than $1 \%$ of the cases in the sample analyzed (see example in section 2 ).

Table 2. Semantic functions of the English Past Progressive

\begin{tabular}{|l|l|l|}
\hline MEANING & CASES & $\%$ \\
\hline PROGRESSIVE & 180 & 53 \\
\hline MEREOLOGICAL PROGRESSIVE & 80 & 23 \\
\hline ANTICIPATORY PAST & 29 & 8 \\
\hline HYPOTHETICAL & 28 & 8 \\
\hline TEMPORARY HABIT & 23 & 7 \\
\hline IRREALIS & 3 & 1 \\
\hline TOTAL & 342 & $100 \%$ \\
\hline
\end{tabular}

\subsubsection{Description: Spanish}

In Spanish <estar + gerund > can be conjugated both as a pretérito and as an imperfecto. Both possibilities have been analysed in order to rule out differences attributable mainly and/or solely to tense.

When conjugated in the imperfecto, this Spanish periphrastic construction yields two basic semantic values.

One is 'temporary habit' $[\mathrm{TH}]$, although this is not a frequent function, as it is displayed in only $3 \%$ of the cases.

Cuando Franco murió estaba viviendo en Yorkshire: "Sentí euforia, aunque duró poco, porque no sabía hasta qué punto la muerte de Franco en sí misma podía cambiar la situación española" [TH] (317IMPPR_SP)

The central meaning of this formal resource in Spanish is clearly 'mereological progressive' [MPR], since as many as $97 \%$ of the textual materials analyzed have this function.

I In Spanish as in English, 'mereological progressive' is a multi-faceted label, as it covers a wide spectrum of meaning(s) including 'inchoative', 'intensive' 5 , 'gradualness' 'iterative', etc. As these more specific ways of characterizing do not seem to be particularly relevant for cross-

linguistic purposes, they will all be considered as one single meaning for the time being. This initial 'working assumption' will be revised once the pretérito forms have been semantically analyzed.

Hacía tiempo que Samaranch estaba buscando a alguien para ser el segundo miembro español y como yo había estado promocionando la candidatura de Barcelona me dijo: "A lo mejor podrías ser tú". [MPR] INTENSIVE (76-IMPPR_SP)

Apenas se hubieron hecho cargo del poder, los revolucionarios cobraron conciencia de que estaba viniendo una coyuntura mundial de baja, acentuada entre nosotros por la trepidación causada por el cambio de régimen. [MPR] INCHOAT (262-IMPPR_SP)

Periphrastic constructions with siempre reveal the same attitudinal semantics as 'subjective progressives' in English (Killie 2004:25). Again, since this more specialized meaning is not expressed by any distinctive expressive means, these cases are treated as 'progressive-intensive' and are considered part of the 'mereological progressive' [MPR] class.

Siempre estaba jugando con algo, con su sombrero, sus bolsillos, con la mesa o las sillas, como si fuesen un teclado." [MPR] INTENSIVE (253-IMPPR_SP) 
Table 3. Semantic functions of Spanish Imperfecto periphrasis

\begin{tabular}{|l|l|l|}
\hline MEANING & CASES & $\%$ \\
\hline MEREOLOGICAL PROGRESSIVE & 326 & 97 \\
\hline TEMPORARY HABIT & 10 & 3 \\
\hline TOTAL & 336 & $100 \%$ \\
\hline
\end{tabular}

The pretérito forms of the periphrasis convey basically the core meaning of 'progressive' [PR] (99\%).

Teresa había conversado un rato con el gobernador de Málaga y su esposa -ésta la $\bullet$ estuvo mirando todo el rato recelosa y fascinada, sin abrir la boca, mientras Teresa y el gobernador acordaban la financiación de un auditorio cultural y tres centros de acogida para toxicómanos-. [PR] DURATION (6PRETP_SP)

Most cases display the slightly more specific meaning of 'progressive-limited duration', which is due to the semantics of the tense. This meaning is usually reinforced by the presence of adverbials ad hoc, as in

Luego te estuve llamando hasta las dos de la madrugada. ¿Dónde te has metido? [PR] DUR LIMITED DURATION (70-PRETP_SP)

The 'iterative' variety of the 'mereological progressive' [MPR] is represented in the sample by just one case, as shown in the table below. In this particular case the 'iterative' meaning is reinforced by the presence of the adverbial, which is the most obvious reason why the periphrasis is used instead of the straight pretérito $^{6}$ No other significant regularities of aspectual use have been identified.

Mi abuela Leonor, que en paz descanse, de la que ya apenas me acuerdo, me contaba cuando yo era niño que su madre se le estuvo apareciendo noche tras noche después de muerta. [PR] INTENSIVO-

ITERATIVO (32-PRETP_SP)

A second meaning of the pretérito forms of the periphrasis would be 'temporary habit' $[\mathrm{TH}](9 \%)$, but most cases can also be easily interpreted in terms of 'progressive-limited duration' as shown by the examples below. As there is no change in meaning if the periphrastic form is replaced by the corresponding pretérito, and 'habit' is not a meaning conveyed by this Spanish form (Rabadán 2005), it seems congruent to consider them as straight 'progressive' forms.

"Desde que llegué de América, entre 1990 y 1998, estuve escribiendo sin apenas estrenar nada.

Básicamente me dediqué al noble arte de sobrevivir", [PR] DUR LIMITED DURATION (34-PRETP_SP)

Desde niño, hasta los 16 años, estuve viviendo en el desierto del Sahara y de esa época es mi primer libro, El viento y la arena, que son recuerdos de aquel tiempo de aislamiento y soledad en el desierto. [PR] DUR LIMITED DURATION (157-PRETP_SP)

A ella la vi algunas veces -dijo- porque ese hombre, antes de esconderse en la buhardilla, 0 estuvo viviendo en el segundo y allí le visitaba, y los dos bajaban y subían como una pareja que se quiere. [PR] DUR (163-PRETP_SP)

Table 4. Semantic functions of Spanish pretérito periphrasis

\begin{tabular}{|l|l|l|}
\hline MEANING & CASES & $\%$ \\
\hline PROGRESSIVE & 168 & $99 \%$ \\
\hline MEREOLOGICAL PROGRESSIVE & 1 & $1 \%$ \\
\hline TOTAL & 169 & $100 \%$ \\
\hline
\end{tabular}




\subsection{Juxtaposition English-Spanish: The Comparable Data.}

The juxtaposition of the results obtained from The Bank of English and CREA shows the differences in the distribution of meanings in English and in Spanish (see Table 8). The main finding concerns the scope of the progressive meaning(s) expressed by the English form and by $<$ estar + gerund $>$ in Spanish. The English Past Progressive emerges as an extremely versatile and flexible form, able to convey a large variety of meanings. By contrast, <estar + gerund $>$ appears as a highly 'specialized' construction, able to convey a far more restricted range of meaning(s). According to our empirical data, the central meaning of the English form is plain 'progressive (53\%), whereas this particular function is extremely restricted in the Spanish data (1\%). A second typical meaning expressed by the Past Progressive is 'mereological progressive' (23\%), which turns out to be the central meaning of <estar + gerund $>$ both in the imperfecto and perfecto tenses. Both the English and the Spanish forms can express 'temporary habit', although this function seems to be more frequent in the case of English (7\%) than Spanish (3\%). There are three meanings - 'anticipatory past', 'hypothetical', and 'irrealis'- that belong in the sphere of unreal, modalized meanings and cannot be conveyed by <estar + gerund $>$ when conjugated in either of the two past tenses.

Table 5. Juxtaposition English-Spanish progressive forms

\begin{tabular}{|l|l|l|l|}
\hline ENG PRP & MEANING & SP IMPP & SP PRETP \\
\hline $53 \%$ & PROGRESSIVE & & $1 \%$ \\
\hline $23 \%$ & MEREOLOGICAL PROGRESSIVE & $96 \%$ & $99 \%$ \\
\hline $8 \%$ & ANTICIPATORY PAST & & \\
\hline $8 \%$ & HYPOTHETICAL & & \\
\hline $7 \%$ & TEMPORARY HABIT & $3 \%$ & \\
\hline $1 \%$ & IRREALIS & & \\
\hline 100 & TOTAL & 100 & 100 \\
\hline
\end{tabular}

At this point, this study needs further empirical evidence in order to 'fill in' the cross-linguistic voids revealed at the juxtaposition stage and to verify whether there are alternative means of expression for the meaning(s) shared by both the English and the Spanish forms. The new evidence will be obtained from the translation ACTRES corpus.

\subsection{Contrast: The Comparable and The Translation Data}

The translation corpus supplied the 'translation solutions' provided for English Past Progressive forms at the cross-linguistic labelling phase. The next step is to map the meanings displayed by these 'formal Spanish solutions' and search for possible regularities of form-meaning distribution. Table 9 displays the results. The most obvious and evident regularity is that Spanish prefers a straight imperfecto (as opposed to a periphrastic form) to express the central meanings of the English Past Progressive, that is, 'progressive' and 'temporary habit'. The periphrastic forms are preferred when the meaning conveyed is 'mereological progressive', and alternative aspectual periphrases (empezar a + inf; seguir + ger; ir + ger, etc.) may be used if the particular 'aspect' content is not sufficiently reinforced by the context. Instances of 'hypothetical' have been translated by means of a non-perihrastic subjunctive imperfecto, and 'anticipatory past' cases have been reinterpreted by means of modal constructions reflecting meanings slightly different from those in the original text ${ }^{7}$. No regularity has been found for the rest of the solutions $(16 \%)$. 
Table 6. Form-meaning distribution in translated text into Spanish

\begin{tabular}{|c|c|c|}
\hline SPANISH SOLUTIONS & MEANINGS & $\mathrm{N} \%$ \\
\hline \multirow{2}{*}{ IMPERFECTO } & PROGRESSIVE & 46 \\
\hline & TEMPORARY HABIT & 2 \\
\hline PROG PERIPHRASES IMP & MEREOLOGICAL PROGRESSIVE & 20 \\
\hline OTHER PERIPHRASES IMP & $\begin{array}{l}\text { MEREOLOGICAL PROGRESSIVE (iterative, continuative, } \\
\text { reiterative, inchoative) }\end{array}$ & 8 \\
\hline IMPERFECTO SUBJ & HYPOTHETICAL & 4 \\
\hline $\begin{array}{l}\text { MODAL CONSTRUCTIONS } \\
\text { CONDITIONAL }\end{array}$ & ANTICIPATORY PAST & $\frac{3}{1}$ \\
\hline PRETERITO & \multirow{3}{*}{$?$} & 7 \\
\hline PRESENT TENSES & & 5 \\
\hline PERFECT TENSES & & 4 \\
\hline
\end{tabular}

\section{Conclusion: Descriptive Data For 'Proactive' Applications}

The empirical data (table 6) reveal that $16 \%$ of the solutions provided for this 'problem' in regular Spanish translations do not convey the meaning of the original. These changes cannot be explained or justified in terms of 'higher level' translation decisions, or any type of translation norm (in the descriptive sense). Probably the simplest explanation is also the real one: the translating agent 'perceived' that a periphrastic form was not needed there, but he/she did not have ready access to tools in order to decide why this was so and how it could be dealt with.

This is the need addressed by our proposal- to provide empirically based information to be fed directly into a tool. Table 7 shows what has been called throughout this paper a 'descriptively prescriptive' inventory of translation solutions available. It is descriptive because it relies on empirical descriptive data, and it is prescriptive because it rules out from the inventory those options that are not correct (i.e. they do not encode the meaning expressed in the original).

According to these data, any instance of the English Past Progressive in an original text would be analyzed for meaning using the labels provided here, and a translation solution would be chosen from those in the inventory.

Table 7 . English-Spanish semantic function-translation solution interface.

\begin{tabular}{|c|c|c|}
\hline TR PROBLEM & MEANINGS & SOLUTIONS AVAILABLE \\
\hline \multirow{11}{*}{$\begin{array}{l}\text { ENGLISH } \\
\text { PAST } \\
\text { PROGRESSIVE }\end{array}$} & \multirow{2}{*}{ PROGRESSIVE } & IMPERFECTO \\
\hline & & $<$ ESTAR + GER $>$ PRETERITO \\
\hline & \multirow{2}{*}{ MEREOLOGICAL PROGRESSIVE } & $<$ ESTAR + GER $>$ IMPERFECTO \\
\hline & & OTHER PERIPHRASES \\
\hline & \multirow{2}{*}{ TEMPORARY HABIT } & IMPERFECTO \\
\hline & & $<$ ESTAR + GER > IMPERFECTO \\
\hline & \multirow{2}{*}{ ANTICIPATORY PAST } & CONDITIONAL TENSE \\
\hline & & MODAL CONSTRUCTIONS \\
\hline & HYPOTHETICAL & IMPERFECTO SUBJUNCTIVE \\
\hline & \multirow{2}{*}{ IRREALIS } & * IMPERFECTO \\
\hline & & * CONDITIONAL TENSE \\
\hline
\end{tabular}

* See Rabadán (forthcoming) and Rabadán (2005).

The long term goal is to produce an electronic, translation-bench compatible application including the type of information displayed in the table above. Being able to recall this type of applicationoriented data (in whatever format is considered most user-friendly) at any time when translating or 
assessing or revising will be a time-saving device for a number of activities, and will help avoid unwanted 'deviations' and errors.

\section{NOTES}

* Research for this paper was funded partly by the Spanish Ministry of Science and Technology and FEDER (MCyT BFF2001-0112) within the ACTRES Project (Contrastive Analysis and Translation English-Spanish). Many thanks to Roda P. Roberts for her comments and terminological suggestions.

1. Some linguists, including Bello (1990: $§ 617,619)$ consider $<$ Estar + gerund $>$ a compound verbal form and therefore part of the paradigm.

2. There is also a clearly higher occurrence of this tense in the 'books' subcorpus and it is absent in the 'newspapers' subcorpus materials, which could have implications concerning the types of meanings conveyed.

3. These are: see, mean, come, call, try, play, live, hold, begin and lead.

4. The Spanish lemmas are: creer, dejar, mirar, tomar, perder, acercar, aparecer, escribir, comer, acordar, gustar, entrar, buscar, resultar, traer, mantener, olvidar, permitir, pasar, salir, conocer, entender, comprender, existir, dirigir, quitar, responder, pensar, llamar, esperar, levantar, coger, estudiar, subir, correr, jugar, parecer, venir, recordar, pedir, hablar, sentir, vivir, leer and meter. The frequency list used for the Spanish data has been provided by Guillermo Rojo. See Rabadán (forthcoming).

5 . There are instances of 'intensive' meaning where a more general 'progressive' [PR] interpretation would possibly be more acceptable, as 'intensive' is the most frequent meaning of <estar + gerund $>$ in Spanish. There are also cases where the difference is neutralized for contextual reasons. For cross-linguistic convenience, however, I will maintain the difference and consider two separate meanings.

6. The telic, 'end-closure' feature typical of the pretérito would have forced a view of the 'apparitions' as completely separate, independent events, whereas the periphrastic form allows for a 'continuous' view of the action and therefore for considering it as just one event.

7. The usual 'plan, arrangement' of the English form can very easily be turned into 'intention'. E. g. He wasn't going anywhere. He was lost in another place now.// No pensaba irse de allí. Estaba perdido en otro lugar.

(40_prACTRES).

\section{REFERENCES}

Bello, A. (1990): Gramática de la lengua castellana, Madrid, Edaf.

Bonomi, A. (1997): “The Progressive and the Structure of Events", Journal of Semantics 14, p. 173-205.

Chesterman, A. (1998): Contrastive Functional Analysis, Amsterdam and Philadelphia, John Benjamins.

COPlEy, B. (2000): "Futurate Meanings" http://www-rcf.usc.edu/ copley/copley.plc.28.pdf (accesed 03/03/05),

p. 1-14.

FERnÁNDEZ DE CASTRO, F. (1999): Las perífrasis verbales en español actual, Madrid, Gredos.

Fleischman, S. (1995): "Imperfective and Irrealis", Joan Bybee and Suzanne Fleischman, (eds.) Modality and grammar in discourse, Amsterdam and Philadelphia, John Benjamins, p. 519-551.

Gómez Torrego, L. (1988): Perífrasis verbales, Madrid, Arco.

Higgingbotham, J. (2004): “The English Progressive”, J. GuÉron and J. LeCARme (eds.) The Syntax of Time, Cambridge, Mass and London, UK, MIT Press, p. 329-358.

Huddleston, R. D. and G. K. Pullum (2002): The Cambridge Grammar of the English Language, Cambridge, UK and New York, Cambridge University Press.

KILLIE, K. (2004): "Subjectivity and the English progressive", English Language and Linguistics 8-1, p. 25-46. Kratzer, A. (2004): "Telicity and the Meaning of Objective Case”, J. GuÉRON and J. LeCARME (eds.) The Syntax of Time, Cambridge, Mass and London, UK, MIT Press, p. 389-424.

LACA, B. (2004): “Romance 'Aspectual' Periphrases: Eventuality Modification versus 'Syntactic' Aspect”, J.

GuÉron and J. LeCARME (eds.) The Syntax of Time, Cambridge, Mass and London, UK, MIT Press, p. 425-440.

LEECH, G. N. (1987): Meaning and the English Verb, London adn NY, Longman, $2^{\text {nd }}$ edition. 
PÉREZ , R. (1998): “Realizaciones del contenido modal irrealidad en el sistema verbal español”, G. LUQUET (ed) Travaux de Linguistique Hispanique, Paris, Presses de la Sorbonne Nouvelle, p. 385-399.

PORTNER, P. (1998): “The Progressive in Modal Semantics”, Language 74, 760-87.

PRAT, A. E. (1996): "The Realisation of the Semantic Operator Progressive in English and Romance Languages", Language Sciences 18-1/2, p. 95-303.

RABADÁN, R. (forthcoming): “Translating the 'Predictive' and 'Hypothetical' Meanings English-Spanish”.

RABADÁN, R. (2005): “The Applicability of Description: Empirical Research And Translation Tools”, C.

Toledano (ed) Contemporary Problematics of Translation Studies, Revista Canaria de Estudios Ingleses 51 . (In press).

RABADÁn, R., B. LABRADOR and N. RAMÓN (2004): "English-Spanish Corpus-Based Contrastive Analysis:

Translational Applications from the ACTRES Project”, Barbara Lewandowska-Tomaszczyk (ed), Practical

Applications in Language Corpora (PALC 2003), Hamburg, Peter Lang, p. 141-152.

SCHEFFER, J. (1975): The Progressive in English, Amsterdam, North Holland.

Toury, G. (1995): Descriptive Translation Studies And Beyond, Amsterdam and Philadelphia, John Benjamins.

WiLliams, C. (2002): Progressive and non-progressive aspect in English, Fasano, Schena.

YlLERA, A. (1999): "Las perífrasis verbales de gerundio y participio", V. DEMONTE and I. BosQUE (dir.) Gramática descriptiva de la lengua española, Madrid, Espasa, p. 3392-3441. 